\title{
FAKTOR-FAKTOR YANG MEMPENGARUHI FINANCIAL DISTRESS DENGAN PENDEKATAN ALTMAN Z-SCORE PADA PERUSAHAAN PERTAMBANGAN YANG TERDAFTAR DI BURSA EFEK INDONESIA TAHUN 2015-2017
}

\author{
Fitria Marlistiara Sutra', Rimi Gusliana Mais ${ }^{2}$ \\ Program Studi Akuntansi \\ Sekolah Tinggi Ilmu Ekonomi Indonesia Jakarta Indonesia \\ tiarasutra@gmail.com ${ }^{1}$, rimigusliana@gmail.com²
}

\begin{abstract}
Abstrak - Tujuan dari penelitian ini adalah untuk mengetahui dan menganalisis pengaruh profitabilitas, likuiditas, leverage, operating capacity dan sales growth terhadap financial distress pada Perusahaan Pertambangan yang Terdaftar di Bursa Efek Indonesia tahun 2015-2017. Objek yang diteliti adalah perusahaan pertambangan yang terdaftar di Bursa Efek Indonesia tahun 2015-2017. Populasi dalam penelitian ini sebanyak 41 perusahaan pertambangan yang terdaftar di Bursa Efek Indonesia, Adapun sampel ditentukan sebanyak 32 perusahaan pertambangan yang terdaftar di Bursa Efek Indonesia periode 20152017. Analisis data yang digunakan dalam penelitian ini adalah statistik deskriptif, uji asumsi klasik, pemilihan model, analisis regresi linier berganda, koefisien determinasi $\left(\mathrm{r}^{2}\right)$ dan uji hipotesis. Hasil penelitian menyimpulkan bahwa profitabilitas berpengaruh negatif terhadap financial distress, Likuiditas berpengaruh negatif terhadap financial distress, Leverage tidak berpengaruh positif terhadap financial distress, Operating Capacity berpengaruh negatif terhadap financial distress dan Sales Growth tidak berpengaruh negatif terhadap financial distress.
\end{abstract}

Kata Kunci : Financial Distress, Altman Z-Score

\section{PENDAHULUAN}

Perkembangan ekonomi dunia dalam beberapa tahun terakhir telah mengalami kemajuan yang sangat pesat. Kemajuan yang sangat pesat ini disebabkan oleh semakin kuat dan meluasnya globalisasi di seluruh dunia. Bisnis yang kuat dan berpengalaman akan semakin mendapat keuntungan akan meluasnya pengaruh globalisasi. Akan tetapi di sisi lain, sebagai bisnis yang baru tumbuh ataupun bisnis yang berskala nasional akan sulit untuk bersaing dengan perusahaan asing, sehingga dampaknya adalah perusahaan yang berskala kecil akan mengalami krisis keuangan dalam perusahaan mereka.

Dalam perkembangan globalisasi, ada beberapa dampak buruk yang bisa dirasakan, salah satunya adalah global financial crisis pada tahun 2008 yang berakibat 
pada melemahnya aktivitas bisnis secara umum. Sebagian besar negara di seluruh dunia mengalami kemunduran dan bencana keuangan karena pecahnya krisis keuangan tersebut. Krisis keuangan tersebut telah menyebabkan kebangkrutan beberapa perusahaan publik di Amerika Serikat, Eropa, Asia, dan negara-negara lainnya. Di samping itu, di lingkungan dalam negeri, ada beberapa dampak atas terjadinya krisis keuangan tersebut, salah satunya adalah terdapat beberapa perusahaan yang menjadi delisting akibat dari krisis tersebut. Perusahaan bisa di de-listing dari Bursa Efek Indonesia (BEI) disebabkan karena perusahaan tersebut berada pada kondisi financial distress atau sedang mengalami kesulitan keuangan (Pranowo dalam Hidayat et al, 2014).

Suatu perusahaan mengalami kondisi financial distress terlebih dahulu sebelum akhirnya perusahaan tersebut mengalami kebangkrutan. Hal ini disebabkan karena pada saat tersebut keadaan keuangan yang terjadi di perusahaan dalam keadaan yang krisis, dimana dalam keadaan seperti ini dapat dikatakan bahwa perusahaan mengalami penurunan dana dalam menjalankan usahanya yang dapat disebabkan karena adanya penurunan dalam pendapatan dari hasil penjualan atau hasil operasi yang dilakukan oleh perusahaan untuk mendapatkan laba, namun pendapatan atau hasil yang diperoleh tidaklah sebanding dengan kewajiban-kewajiban atau hutang yang banyak dan telah jatuh tempo.

Studi mengenai kebangkrutan perusahaan pertama kali dikemukakan oleh Beaver pada tahun 1966 yang menggunakan rasio keuangan perusahaan pada lima tahun sebelum terjadi kebangkrutan. Metode ini kemudian diperbaiki oleh Altman tahun 1968. Metode Altman memperbaiki kelemahan-kelemahan dari pendekatan univariate. Metode multivariate memasukan variabel-variabel penelitian dalam suatu persamaan dan diuji secara bersamaan. Penelitian ini menggunakan metode Z-score Altman dalam memprediksi kebangkrutan. Tujuannya adalah ingin mengetahui perusahaan yang paling mengindikasikan kebangkrutan dan seberapa besar tingkat kemungkinan kebangkrutannya. Model Z-score Altman merupakan model yang tepat dan akurat dalam membahas penelitian-penelitian mengenai analisis kebangkrutan perusahaan dibandingkan metode-metode lain. Penelitian ini membahas tentang prediksi kebangkrutan pada perusahaan-perusahaan pertambangan yang terdaftar di Bursa Efek Indonesia karena adanya fenomena-fenomena yang terjadi di perusahaan pertambangan. 
Fenomena tersebut diawali pada tahun 2000, para ahli memperkirakan sedikit sekali investor baru yang akan masuk ke sektor pertambangan di Indonesia karena risikonya tinggi. Para ahli berharap sektor pertambangan bisa menjadi sektor pemicu bagi perekonomian untuk bangkit, setelah krisis moneter tahun 1997 (Diratama, 2018).

Fenomena yang terjadi adalah perusahaan pertambangan dunia masih memandang kondisi investasi di Indonesia tidak sebaik negara-negara lain di dunia. Slamet (2017) menjelaskan lesunya bisnis batu bara disebabkan turunnya harga minyak mentah. Minimnya permintaan akan komoditas batu bara yang diikuti penurunan harga merupakan krisis dalam perusahaan batu bara. Salah satunya, ditandai dengan ditutupnya 125 perusahaan pertambangan batu bara yang ada di Kalimantan Timur, jika krisis berkelanjutan, maka perusahaan bangkrut akan terus bertambah menjadi 200 perusahaan. Data statistik Bursa Efek Indonesia (BEI) pada tahun 2015-2016 yang menunjukan tingkat kerugian terbesar (greating loss) adalah sektor pertambangan. Fakta ini bisa dilihat dari persentase kerugian trading saham sektor pertambangan. Perdagangan saham pada sektor pertambangan mengalami kerugian pada tahun 2015 dengan tingkat persentase one day $-39,45 \%$ sedangkan pada tahun 2016 tingkat persentasi one day meningkat sebesar $-43,45 \%$, one week pada tahun 2015 sebesar 6,12\% dan one week pada tahun 2016 sebesar $-8,46 \%$, sedangkan one month tahun 2015 sebesar $-14.94 \%$ dan one month tahun 2016 sebesar -14,62\%. Saham-saham yang terdapat dalam perusahaan pertambangan terus mengalami kerugian sampai tahun 2016, baik itu secara persentasi harian, mingguan, dan bahkan bulanan (Diratama, 2018).

Kerugian saham yang dialami perusahaan tambang disebabkan lemahnya permintaan terhadap saham. Sementara fenomena kebangkrutan ini juga dapat dilihat dari salah satu perusahaan pertambangan. Seperti pada laporan keuangan perusahaan PT Elnusa Tbk dalam jutaan rupiah menunjukan bahwa pada tahun 2015 jumlah aset lancar sebesar Rp. 2.079.319 sedangkan pada jumlah aset tidak lancar sebesar Rp. 2.328.194 kemudian untuk jumlah laba di tahan sebesar Rp.1.722.099, pada tahun yang sama untuk jumlah laba sebelum bunga dan pajak sebesar Rp. 507.738 dan untuk penjualan sebesar Rp. 3.775.323. Pada tahun 2016 PT Elnusa Tbk memiliki aset lancar sebesar Rp. 1.865.116 sementara jumlah aset tidak lancarnya sebesar Rp. 2.325.840, untuk laba di tahan berjumlah sebesar Rp.1.500.931, pada tahun yang sama jumlah dari laba sebelum bunga dan pajak sebesar Rp. 418.318 dan penjualan berjumlah sebesar Rp. 
3.620.570. Berdasarkan penjalasan di atas PT Elnusa Tbk tidak berhasil mempertahan kinerja dengan baik, dilihat dari pertumbuhan aset yang menurun, laba ditahan kemudian penurun sebelum bunga dan pajak serta penjualan perusahaan dari tahun 2015-2016.

Kerugian saham yang dialami perusahaan tambang disebabkan lemahnya permintaan terhadap saham. Fenomena-fenomena ini perlu menjadi bahan evaluasi bagi pemerintah untuk mengambil kebijakan di masa yang akan datang. Masalah ini apabila tidak ditindak lanjuti akan berdampak buruk pada perusahaan-perusahaan pertambangan lainnya. Penelitian Fathuddin (2012), menunjukkan bahwa pada tahun 2005-2006 dari 7 perusahaan yang ada terdapat 2 perusahaan yang diprediksi tidak bangkrut, yaitu PT Internasional Nickel Indonesia dan PT Tambang Batubara Bukit Asam. Perusahaan yang mengalami kebangkrutan, yaitu PT Energi Mega Persada dan PT Medco Energi Internasional dengan menggunakan model Z-score Altman. Pertambangan termasuk ke dalam jenis saham spekulatif, yaitu saham yang kondisinya memiliki tingkat spekulasi yang tinggi (Fahmi, 2012:83). Berdasarkan data harga komoditas dari Bank Indonesia (2017), menujukkan bahwa kondisi beberapa komoditas seperti batubara, minyak mentah, tembaga dan nikel menujukkan bahwa rata-rata harga komoditas sektor pertambangan cenderung mengalami penurunan selama tahun 2012 hingga 2016. Hal tersebut berarti bahwa kondisi sektor pertambangan selama lima tahun terakhir masih terus melemah dan belum mengalami pemulihan.

Penyebab terjadinya pelemahan kondisi harga komoditas dan harga saham sektor pertambangan salah satunya dapat dilihat dari laporan keuangan perusahaan tersebut. Menurut Hery (2015:5), laporan keuangan berfungsi sebagai alat informasi yang menghubungkan perusahaan dengan pihak-pihak yang berkepentingan, yang menunjukkan kondisi kesehatan keuangan perusahaan dan kinerja perusahaan. Alat yang digunakan untuk mengukur kinerja keuangan perusahaan yaitu dengan analisis rasio keuangan. Dimana, tujuan analisis rasio keuangan adalah untuk membantu perusahaan mengetahui kekuatan dan kelemahan keuangan perusahaan, menilai kinerja laporan keuangan perusahaan dalam memberdayakan seluruh sumber daya yang ada untuk mencapai target perusahaan (Sujarweni, 2017:59). Dalam mengevaluasi kinerja keuangan dapat dilakukan dengan membandingkan rasio keuangan suatu perusahaan terhadap rata-rata industri perusahaan yang sejenis secara bersamaan (Surjoko et al, 
2012). Financial Distress pada perusahaan pertambangan diduga dipengaruhi oleh faktor-faktor internal perusahaan yaitu profitabilitas, likuiditas, leverage, operating capacity dan sales growth.

Penelitian ini memfokuskan pada faktor-faktor yang mempengaruhi kondisi financial distress pada perusahaan pertambangan. Financial distress ini dapat dilihat dengan berbagai cara, seperti kinerja keuangan yang semakin menurun, ketidak mampuan perusahaan membayar kewajiban, adanya penghentian pembayaran deviden, masalah arus kas yang dihadapi perusahaan, kesulitan likuiditas, adanya pemberhentian tenaga kerja, dan kondisi-kondisi lainnya yang mengindikasikan financial distress yang dihadapi oleh perusahaan. Berdasarkan latar belakang penelitian, maka variabel dependen yang diteliti adalah profitabilitas, likuiditas, leverage, operating leverage dan sales growth.

Variabel profitabilitas, likuiditas, leverage, operating leverage dan sales growth menarik untuk diteliti pengaruhnya terhadap financial distress karena terdapat inkonsistensi hasil penelitian terdahulu, dimana pada penelitian Hidayat et al (2014) menyimpulkan bahwa profitabilitas tidak berpengaruh signifikan terhadap financial distress, sedangkan penelitian Alexanders (2017) menyimpulkan bahwa profitabilitas berpengaruh signifikan terhadap financial distress. Penelitian Hanifah et al (2013) menyimpulkan bahwa likuiditas tidak berpengaruh signifikan terhadap financial distress, sedangkan penelitian Hidayat et al (2014) menyimpulkan bahwa likuiditas berpengaruh signifikan terhadap financial distress. Penelitian Widhiari et al (2015) menyimpulkan bahwa leverage tidak berpengaruh signifikan terhadap financial distress, sedangkan Hidayat et al (2014) menyimpulkan bahwa leverage berpengaruh signifikan terhadap financial distress. Penelitian Yustika (2015) menyimpulkan bahwa operating capacity tidak berpengaruh signifikan terhadap financial distress, sedangkan penelitian Widhiari et al (2015) menyimpulkan bahwa operating capacity berpengaruh signifikan terhadap financial distress. Penelitian Liana et al (2014) menyimpulkan bahwa sales growth tidak berpengaruh signifikan terhadap financial distress, sedangkan penelitian Widhiari et al (2015) menyimpulkan bahwa sales growth berpengaruh signifikan terhadap financial distress.

Terdapat perbedaan antara penelitian ini dengan penelitian terdahulu, dimana variabel independen yang dibahas berbeda-beda, perusahaan yang diteliti berbeda serta 
periode tahun penelitian yang berbeda. Berdasarkan latar belakang masalah tersebut di atas, maka penulis tertarik untuk meneliti dan menggali lebih jauh tentang prediksi kebangkrutan pada perusahaan pertambangan yang terdaftar di Bursa Efek Indonesia pada tahun 2015 sampai 2017. Penulis tertarik untuk membahas lebih lanjut melalui penelitian dengan judul "Faktor-Faktor yang Mempengaruhi Financial Distress dengan Pendekatan Altman Z-Score pada Perusahaan Pertambangan Yang Terdaftar di Bursa Efek Indonesia tahun 2015-2017”.

Perumusan masalah dalam penelitian ini adalah apakah profitabilitas, likuiditas, leverage, operating capacity dan sales growth berpengaruh terhadap financial distress. Dengan demikian penelitian ini bertujuan untuk mengetahui dan menganalisis pengaruh profitabilitas, likuiditas, leverage, operating capacity dan sales growth terhadap financial distress pada Perusahaan Pertambangan yang Terdaftar di Bursa Efek Indonesia tahun 2015-2017.

\section{KAJIAN PUSTAKA, KERANGKA PEMIKIRAN DAN HIPOTESIS}

\section{Agency Theory}

Teori keagenan (Agency Theory) mendeskripsikan hubungan antara pemegang saham (shareholders) sebagai prinsipal dan manajemen sebagai agen. Manajemen merupakan pihak yang dikontrak oleh pemegang saham untuk bekerja demi kepentingan pemegang saham. Karena mereka dipilih, maka pihak manejemen harus mempertanggungjawabkan semua pekerjaannya kepada pemegang saham. Hubungan keagenan merupakan suatu kontrak dimana satu atau lebih orang (prinsipal) memerintah orang lain (agen) untuk melakukan suatu jasa atas nama prinsipal serta memberi wewenang kepada agen membuat keputusan yang terbaik bagi prinsipal. Jika kedua belah pihak tersebut mempunyai tujuan yang sama untuk memaksimumkan nilai perusahaan, maka diyakini agen akan bertindak dengan cara yang sesuai dengan kepentingan prinsipal. Masalah keagenan potensial terjadi apabila bagian kepemilikan manajer atas saham perusahaan kurang dari seratus persen. Dengan proporsi kepemilikan yang hanya sebagian dari perusahaan membuat manajer cenderung bertindak untuk kepentingan pribadi dan bukan untuk memaksimumkan perusahaan. Inilah yang nantinya akan menyebabkan biaya keagenan (agency cost). Jensen dan Meckling dalam Ambarwati (2014) mendefinisikan agency cost sebagai jumlah dari biaya yang dikeluarkan prinsipal untuk melakukan pengawasan terhadap agen. Hampir 
mustahil bagi perusahaan untuk memiliki zero agency cost dalam rangka menjamin manajer akan mengambil keputusan yang optimal dari pandangan shareholders karena adanya perbedaan kepentingan yang besar diantara mereka. Pengawasan atau monitoring yang dilakukan oleh pihak independen memerlukan biaya atau monitoring cost dalam bentuk biaya audit, yang merupakan salah satu dari agency cost (Jensen dan Meckling dalam Pratiwi et al, 2015). Biaya pengawasan (monitoring cost) merupakan biaya untuk mengawasi perilaku agent apakah agent telah bertindak sesuai kepentingan principal dengan melaporkan secara akurat semua aktivitas yang telah ditugaskan kepada manajer. Uraian tersebut diatas memberi makna bahwa auditor merupakan pihak yang dianggap dapat menjembatani kepentingan pihak pemegang saham (principal) dengan pihak manajer (agent) dalam mengelola keuangan perusahaan (Setiawan, 2012) termasuk menilai kelayakan strategi manajemen dalam upaya untuk mengatasi kesulitan keuangan perusahaan.

\section{Signaling Theory}

Teori Signal (signalling theory) adalah teori yang dikemukakan oleh Ross dalam Firmansyah (2017). Dalam teori ini dikemukakan bahwa teori sinyal digunakan untuk menjelaskan bahwa laporan keuangan digunakan untuk memberi sinyal positif (good news) maupun sinyal negatif (bad news) kepada pemakainya. Sinyal ini berupa informasi mengenai apa yang sudah dilakukan oleh manajemen untuk merealisasikan keinginan pemilik. Teori sinyal juga dapat digunakan pihak perusahaan (agen), principal (investor) maupun pihak lain untuk mengurangi asimetri informasi dengan menghasilkan laporan keuangan yang berkualitas. Laporan keuangan merupakan proses analisis serta penilaian yang dapat membantu dalam menjelaskan tujuan yang telah dicapai suatu perusahaan. Laporan keuangan sangatlah penting untuk setiap perusahaan, karena dapat digunakan untuk mengetahui kinerja dan kondisi keuangan perusahaan sehingga dapat memprediksi adanya potensi kebangkrutan dimasa yang akan datang. Keputusan investor dapat dipengaruhi oleh kualitas informasi yang diungkapkan perusahaan. Kualitas informasi tersebut mempunyai tujuan untuk menjelaskan detail informasi yang bisa menjadi pemicu salah duga yang timbul karena manajer lebih mengetahui informasi internal dan prospek perusahaan dimasa mendatang dibanding pihak eksternal. Investor terlebih dahulu menginterpretasikan dan menganalisis informasi tersebut sebagai sinyal baik (good news) atau sinyal buruk 
(bad news). Jika informasi tersebut sebagai sinyal baik maka investor akan tertarik untuk mengambil langkah lebih lanjut. Begitu pula sebaliknya, apabila sinyal buruk lebih tercermin dari informasi yang dihasilkan maka investor akan beralih dan mencari perusahaan lain yang mempunyai informasi yang lebih baik.

\section{Building Theory}

Kasus demi kasus analisis perusahaan yang mencapai pembalikan penurunan keuangan perusahaan mengungkapkan adanya penghematan sebagai pendahulu dalam melakukan strategi pemulihan yang sukses. Daftar peneliti telah menyimpulkan bahwa, untuk perusahaan dengan kinerja sangat menurun, perputaran upaya yang dirancang untuk menstabilkan operasi dan mengembalikan profitabilitas hampir selalu melibatkan pemotongan biaya yang ketat, dilengkapi dengan menyusut kembali kepada segmen bisnis yang muncul untuk menawarkan prospek margin yang baik di masa depan (Hambrick dan Schecter, D'Aveni, Dumaine, Grinyer dan McKierna dalam Pearce, 2009:34). Penelitian yang dilaporkan didasarkan pada pengetahuan yang ada tentang bisnis turnaround dengan pergeseran keuntungan dalam ukuran rasio keuangan selama tiga tahap yang khas dalam siklus perputaran. Dengan mengevaluasi besar dan arah perubahan dalam langkah-langkah keuangan setiap fase dari perputaran, penelitian ini memperkenalkan model tahapan untuk pemulihan kinerja yang unggul termasuk padapenurunan (Bibeault dalam Pearce, 2009:36) mengatakan wawasan dari research past telah menghasilkan bukti bahwa tanggapan terhadap kemerosotan keuangan perusahaan, turnaround yang sukses mencakup dua set kegiatan strategis yang mendekati penurunan dan pemulihan tahapan siklus bisnis yaitu penghematan dan pemulihan. Dari berbagai penjelasan tersebut, penulis berpendapat mengenai building theory merupakan pengidentifikasian langkah-langkah yang mendiskriminasikan antara perusahaan yang berhasil mencapai perubahan (turnaround) dan perusahaan yang tidak berhasil mencapai perubahan (non turnaround). Dengan demikian, building theory melandasi penelitian ini yang digunakan untuk menjelaskan bahwa untuk perusahaan yang berhasil pulih dari kondisi perusahaan yang mengalami tahap penurunan (financial distress) banyak dipengaruhi dan memiliki hubungan dengan kinerja keuangan perusahaan sebagai pendahulu dalam melakukan strategi pemulihan yang sukses atau disebut keberhasilan turnaround. 


\section{Financial Distress}

Financial distress merupakan kondisi penurunan keuangan yang dialami oleh suatu perusahaan selama beberapa tahun berturut-turut sehingga dapat mengakibatkan kebangkrutan (Platt dan Platt dalam Hanifah et al, 2013). Khaliq et al (2014) mendefinisikan financial distress sebagai suatu kondisi dimana perusahaan tidak bisa atau mengalami kesulitan untuk memenuhi kewajibannya kepada kreditur. Peluang terjadinya financial distress meningkat ketika biaya tetap perusahaan tinggi, aset likuid, atau pendapatan yang sangat sensitif terhadap resesi ekonomi. Kondisi ini akan memaksa perusahaan untuk mengeluarkan biaya yang tinggi sehingga manajemen terpaksa melakukan pinjaman kepada pihak lain. Baimwera et al (2014) juga mendefinisikan financial distress sebagai kemungkinan dimana perusahaan tidak dapat memenuhi kewajibannya pada saat jatuh tempo. Pada saat terjadi kesulitan keuangan, ketidakmampuan perusahaan untuk memenuhi kewajiban menunjukkan bahwa perusahaan tersebut kekurangan modal kerja atau working capital. Aghaei dalam Adi et al (2015). Kekurangan modal kerja ini dapat disebabkan oleh beberapa faktor, seperti kewajiban lancar dan biaya operasi yang terlalu tinggi. Jika perusahaan mengalami financial distress dan tidak ada tindakan lebih lanjut untuk perbaikan, perusahaan dapat mengalami kebangkrutan bahkan dapat dilikuidasi. Kebangkrutan adalah keadaan dimana perusahaan gagal atau tidak mampu lagi memenuhi segala kewajiban pemberi pinjaman (debitur) karena perusahaan kekurangan dana untuk menjalankan dan melanjutkan usahanya sehingga pencapaian tujuan ekonomi tidak terpenuhi (Wongsosudono et al, 2013).

Berdasarkan pengertian di atas, maka dapat diinterpretasikan bahwa financial distress keadaan dimana perusahaan mengalami kesulitan keuangan yang ditandai dengan arus kas yang dihasilkan perusahaan tidak cukup untuk memenuhi kewajiban jangka panjang maupun jangka pendek dan perusahaan diharuskan untuk melakukan koreksi terhadap aktivitas perusahaan. Financial distress juga dapat menyebabkan perusahaan mengalami kebangkrutan dan terpaksa mengambil tindakan untuk memperbaiki arus kas.

Altman mengambil sampel dari 66 perusahaan manufaktur untuk dianalisis, dimana setengah diantaranya mengalami kebangkrutan. Dari penelitian tersebut, diperoleh 22 rasio keuangan, dimana lima diantaranya dianggap paling bermanfaat 
terhadap kebangkrutan dan dapat digunakan untuk mendeteksi kebangkrutan perusahaan dua tahun sebelum perusahaan tersebut resmi dinyatakan bangkrut. Model prediksi kebangkrutan oleh Altman memiliki tingkat keakuratan 90\% setahun sebelum perusahaan bangkrut. Namun, untuk tahun kedua sebelum bangkrut tingkat keakuratannya turun menjadi 72\%. Dan terus turun hingga lima tahun sebelum bangkrut, yaitu sebesar 48\%, 29\%, dan 36\%. Ini menunjukkan penurunan kekuatan prediksi rasio keuangan untuk periode waktu yang lebih lama. Altman menguji bobot masing-masing variabel dengan menggunakan analisa regresi, hasil pengujian tersebut digunakan untuk mendapatkan konstanta tertentu sebagai bobot dari masingmasing variabel yang telah ditentukan. Nilai yang didapat dari hasil perhitungan kemudian disesuaikan dengan cut-off value yang telah ditentukan untuk menentukan klasifikasi dari perusahaan tersebut. Z-score Model dikembangkan untuk menggabungkan analisis indeks tradisional dengan statistik yang ketat teknik. Mirip dengan mayoritas model yang digunakan untuk diagnosis awal risiko default bisnis, didasarkan pada analisis diskriminan multivariate. Metode tersebut memungkinkan klasifikasi dengan probabilitas kesalahan sangat rendah dari satu set unit statistik menjadi dua atau lebih kelompok yang diidentifikasi sebelumnya (dalam kasus khusus ini, bisnis yang sehat secara finansial dan bisnis risiko default) berdasarkan beberapa variabel yang diketahui (variabel diskriminan) itu diamati di unit yang sama. Grup memiliki karakteristik homogen yang sama untuk elemen yang termasuk dalam masingmasing kelompok, dan karakteristik heterogen untuk unsur-unsur yang dimiliki kelompok yang berbeda: jika suatu unsur adalah diidentifikasi oleh model yang memiliki karakteristik serupa sebagai kelompok tertentu, itu akan diklasifikasikan melalui proses komparatif dan asosiatif (Danovi \& Quagli, 2012).

Pada awalnya, Altman mengidentifikasi daftar 22 kemungkinan rasio yang menurutnya lebih memadai untuk memprediksi masa depan krisis bisnis berdasarkan tes empiris. Rasio semacam itu selanjutnya digabung menjadi lima kelas makro, masingmasing mampu untuk memberikan informasi yang komprehensif tentang berbagai dimensi struktural bisnis: likuiditas, profitabilitas, leverage, solvabilitas, dan modal yang diinvestasikan. Akhirnya, setelah melalui berbagai tes, Altman memilih lima yang terbaik melakukan rasio karena kemampuan mereka untuk memprediksi potensi kegagalan di masa depan ketika mereka diterapkan bersama. Versi terakhir (1993) dari 
model Z-score adalah sebagai berikut (Celli, 2015)

$Z^{\prime}=1,200 Z_{1}+1,400 Z_{2}+3,300 Z_{3}+0,600 Z_{4}+1,000 Z_{5}$

Keterangan :

$\mathrm{Z}^{\prime}=$ Overall index of bankruptcy

$\mathrm{Z}_{1}=$ Working Capital to Total Assets

$\mathrm{Z}_{2}=$ Retained Earnings to Total Assets

$\mathrm{Z}_{3}=$ EBIT to Total Assets

$\mathrm{Z}_{4}=$ Market Value Equity to Book Value of Total Debt

$\mathrm{Z}_{5}=$ Sales to Total Assets

Kriteria yang digunakan untuk memprediksi kebangkrutan perusahaan model ini adalah, perusahaan yang mempunyai skor $\mathrm{Z}>2,99$ diklasifikasikan sebagai perusahaan sehat, sedangkan perusahaan yang mempunyai skor $Z<1,81$ diklasifikasikan sebagai perusahaan potensial bangkrut. Selanjutnya skor antara 1,81 sampai 2,99 diklasifikasikan sebagai perusahaan pada grey area atau daerah kelabu (Peter et al, 2011).

\section{Profitabilitas}

Menurut Kasmir (2012:196) rasio profitabilitas merupakan rasio untuk menilai kemampuan perusahaan dalam mencari keuntungan. Rasio ini juga memberikan ukuran tingkat efektivitas manajemen suatu perusahaan. Hal ini ditunjukkan oleh laba yang dihasilkan dari penjualan dan pendapatan investasi. Intinya adalah penggunaan rasio ini menunjukkan efisiensi perusahaan. Lebih lanjut Kasmir (2012:196) mengemukakan, penggunaan rasio profitabilitas dapat dilakukan dengan menggunakan perbandingan antara berbagai komponen yang ada dilaporan keuangan, terutama laporan keuangan neraca dan laporan laba rugi. Pengukuran dapat dilakukan untuk beberapa periode operasi. Tujuannya adalah agar terlihat perkembangan perusahaan dalam rentang waktu tertentu, baik penurunan atau kenaikan sekaligus mencari penyebab perubahan tersebut. Rasio profitabilitas dapat diukur dari dua pendekatan yakni pendekatan penjualan dan pendekatan investasi. Ukuran yang banyak digunakan adalah Return on Asset (ROA) dan Return on Equity (ROE), rasio profitabilitas yang diukur dari ROA dan ROE mencerminkan daya tarik bisnis (Bussines Attractive). Return on asset (ROA) merupakan pengukuran kemampuan perusahaaan secara keseluruhan di dalam menghasilkan keuntungan dengan jumlah keseluruhan asset yang tersedia di dalam 
perusahaan. ROA digunakan untuk melihat tingkat efisiensi operasi perusahaan secara keseluruhan. Semakin tinggi rasio ini, semakin baik suatu perusahaan. Salah satu ukuran rasio profitabilitas yang sering juga digunakan adalah Return on Equity (ROE) yang merupakan tolok ukur kemampuan perusahaan dalam menghasilkan laba dengan total modal sendiri yang digunakan. Rasio ini menunjukkan tingkat efisiensi investasi yang nampak pada efektivitas pengelolaan modal sendiri. Cara menilai profitabilitas perusahaan adalah bermacam-macam tergantung dari total aset atau modal mana yang akan diperbandingkan satu dengan yang lainnya. Dalam penelitian ini, pengukuran profitabilitas yang digunakan oleh peneliti adalah ROA (return on assets). ROA ini menggambarkan tingkat pengembalian (return) atas investasi yang ditanamkan oleh investor dari pengelolaan seluruh aset yang digunakan oleh manajemen suatu perusahaan.

\section{Likuiditas}

Rasio likuiditas adalah kemampuan perusahaan untuk melunasi kewajiban jangka pendek tepat pada waktunya. Pengendalian yang cukup diperlukan untuk mempertahankan kegiatan dan kelancaran operasional perusahaan yang bertujuan untuk menghindari adanya tindakan tindakan penyelewengan atau penyalahgunaan oleh karyawan perusahaan. Apabila semakin besar kemampuan perusahaan dalam membayar hutang jangka pendeknya maka akan mempengaruhi berbagai kemungkinan perusahaan akan mendapatkan pembiayaan dari para kreditur jangka pendek untuk mengoprasikan kegiatan usahanya. Rasio likuiditas dapat dihitung berdasarkan informasi modal kerja pos-pos aset lancar dan hutang lancar (Sawir, 2009:16). Menurut Munawir (2009:31), likuiditas menunjukan kemampuan suatu perusahaan untuk memenuhi kewajiban keuangannya yang harus segera dipenuhi atau kemampuan perusahaan untuk memenuhi kewajiban keuangan pada saat ditagih. Maksud dari definisi diatas adalah bahwa perusahaan yang mampu memenuhi kewajiban pada waktunya berarti perusahaan tersebut dalam keadaan likuid, dan perusahaan dikatakan mampu memenuhi kewajiban keuangan tepat pada waktunya apabila perusahaan tersebut mempunyai alat pembayaran ataupun asetlancar yang lebih besar dari pada hutang lancarnya atau hutang jangka pendeknya. Sebaliknya jika perusahaan tidak dapat segera memenuhi kewajiban keuangannya pada saat ditagih, berarti perusahaan tersebut dalam keadaan illikuid. 


\section{Leverage}

Menurut Keown et al (2010:121), leverage keuangan adalah praktek pendanaan sebagian aset perusahaan dengan sekuritas yang menanggung beban pengembalian tetap dengan harapan bisa meningkatkan pengembalian akhir bagi pemegang saham. Menurut Sartono dalam Fahmi (2012:72), rasio leverage adalah mengukur seberapa besar perusahaan dibiayai dengan utang. Penggunaan utang yang terlalu tinggi akan membahayakan perusahaan karena perusahaan akan masuk dalam kategori extreme leverage (utang ekstrim) yaitu perusahaan terjebak dalam tingkat utang yang tinggi dan sulit untuk melepaskan beban utang tersebut. Karena itu sebaiknya perusahaan harus menyeimbangkan beberapa utang yang layak diambil dan dari mana sumber-sumber yang dapat dipakai untuk membayar utang. Adapun menurut Rahardjo (2009:139), solvabilitas adalah kemampuan perusahaan untuk memenuhi seluruh kewajibannya (baik jangka pendek maupun jangka panjang), apabila perusahaan saat itu dilikuidasi. Rasio solvabilitas sering dikenal sebagai leverage ratios yang mengukur kontribusi pemilik (pemodal atau pemegang saham) dibandingkan dengan dana yang berasal dari kreditor. Berdasarkan definisi diatas, maka dapat diinterpretasikan bahwa leverage menunjukkan kemampuan perusahaan untuk untuk memenuhi kewajiban baik itu jangka pendek maupun jangka panjang. Rasio leverage yang biasa digunakan adalah rasio utang (debt ratio) yaitu total utang dibagi dengan total aset. Semakin rendah rasio utang, semakin baik kondisi perusahaan itu. Sebab, artinya hanya sebagian kecil aset perusahaan yang dibiayai dengan utang.

\section{Operating Capacity}

Operating capacity menurut Jiming et al (2011) adalah sebagai berikut: “Operating capacity indicators: it reflects companies' operational efficiency and contains accounts receivable turnover, inventory turnover and total assets turnover."

Berdasarkan dari beberapa definisi diatas sampai pada pemahamn penulis bahwa operating capacity merupakan rasio efisiensi yang berguna untuk mengukur perusahaan dalam penggunaan aset-asetnya. Dengan rasio ini perusahaan dapat mengetahui apakah aset-aset perusahaan telah digunakan secara efisien untuk menghasilkan penjualan atau sebaliknya. Penggunaan aset-aset sangat penting bagi kelangsungan hidup perusahaan. Oleh karena itu jika penggunaan aset semakin efisien maka perusahaan itu semakin baik. Operating capacity diproksikan dengan rasio perputaran aset atau total assets 
turnover. Menurut Fahmi (2012:135) menyatakan bahwa yang dimaksud dengan total asset turnover juga dengan perputaran total aset. Rasio ini melihat sampai sejauh mana keseluruhan aset yang dimiliki oleh perusahaan terjadi perputaran secara efektif. Menurut Kasmir (2012:185) menyatakan bahwa yang dimaksud dengan total asset turnover adalah rasio pengelolaan aset terakhir yang mengukur perputaran seluruh aset perusahaan, dan dihitung dengan membagi penjualan dengan total aset dan mengukur berapa jumlah penjualan yang diperoleh dari setiap rupiah aset. Apabila perusahaan tidak menghasilkan volume usaha yang cukup untuk ukuran investasi sebesar total asetnya, maka penjualan harus ditingkatkan. Menurut Sartono (2010:120) menjelaskan bahwa yang dimaksud dengan total asset turnover merupakan rasio yang menunjukan bagaimana efektivitas perusahaan dalam menggunakan keseluruhan aset untuk menciptakan penjualan dan mendapatkan laba. Berdasarkan definisi diatas sampai pada pemahaman penulis bahwa total asset turnover merupakan rasio yang mengukur sampai sejauh mana kemampuan perusahaan dalam menghasilkan penjualan dalam mendapatkan keuntungan. Total asset turnover yang tinggi menunjukan efisiensi penggunaan aset dalam menghasilkan penjualan.

\section{Sales Growth}

Menurut Higgins (2014:63), penjualan adalah penerimaan yang diperoleh dari pengiriman barang dagangan atau dari penyerahan pelayanan dalam bursa sebagi barang pertimbangan yaitu dalam bentuk tunai peralatan kas atau harta lainnya. Sedangkan Fahmi (2012:184) mendefinisikan penjualan adalah penerimaan yang diperoleh dari hasil penjualan produk seperti pengiriman barang (goods) atau pemberian jasa (service) yang diberikan. Adapun pertumbuhan penjualan adalah kenaikan atau penurunan jumlah penjualan dari tahun ke tahun. Semakin meningkat penjualan suatu perusahaan, maka laba yang diperoleh juga meningkat. Perusahaan yang memiliki penjualan relatif stabil akan memiliki aliran kas yang relatif stabil pula, maka dapat menggunakan hutang lebih besar lebih besar daripada perusahaan dengan penjualan yang tidak stabil (Sartono, 2010:122). Swastha (2012:114), mengemukakan bahwa pertumbuhan atas penjualan merupakan indikator penting dari penerimaan pasar dari produk dan/atau jasa perusahaan tersebut, dimana pendapatan yang dihasilkan dari penjualan akan dapat digunakan untuk mengukur tingkat pertumbuhan penjualan. Dengan demikian dapat diketahui bahwa suatu perusahaan dapat dikatakan mengalami pertumbuhan ke arah 
yang lebih baik jika terdapat peningkatan yang konsisten dalam aktivitas utama operasinya. Jadi, pertumbuhan yang terjadi dalam perusahaan dagang sering dikatakan sebagai tingkat pertumbuhan penjualan. Pertumbuhan penjualan perbandingan antara penjualan dari tahun ke tahun atau dari waktu ke waktu. Berdasarkan definisi diatas sampai pada pemahaman penulis bahwa sales growth menggambarkan peningkatan penjualan dari tahun ke tahun. Tingginya tingkat sales growth menunjukan semakin baik suatu perusahaan dalam menjalankan operasinya.

\section{REVIEW HASIL PENELITIAN TERDAHULU}

Penelitian oleh Hidayat et al (2014) dengan judul "Prediksi Financial Distress Perusahaan Manufaktur di Indonesia”. Hasil penelitian ini menunjukkan bahwa rasio leverage (rasio utang), rasio likuiditas (current ratio), dan rasio aktivitas (rasio total asset turnover) adalah rasio keuangan yang memiliki nilai yang signifikan untuk memprediksi kesulitan keuangan di perusahaan, sementara rasio profitabilitas merupakan rasio keuangan yang tidak berpengaruh signifikan untuk memprediksi kesulitan keuangan di perusahaan.

Penelitian Yustika (2015) dengan judul "Pengaruh Likuiditas, Leverage, Profitabilitas, Operating Capacity dan Biaya Agensi Manajerial terhadap Financial Distress (Studi Empiris pada Perusahaan Manufaktur yang Terdaftar di Bursa Efek Indonesia Tahun 2011-2013)". Berdasarkan hasil penelitian menunjukkan bahwa likuiditas, leverage, dan profitabilitas yang memiliki pengaruh signifikan terhadap financial distress. Sementara operating capacity dan biaya agensi manajerial tidak memiliki pengaruh yang signifikan terhadap financial distress.

Penelitian Widhiari et al (2015) dengan judul "Pengaruh Rasio Likuiditas, Leverage, Operating Capacity, dan Sales Growth terhadap Financial Distress". Hasil analisis dari penelitian ini menyatakan bahwa rasio likuiditas, operating capacity dan sales growth mampu mempengaruhi financial distress pada perusahaan manufaktur dengan arah negatif. Sedangkan rasio leverage tidak mampu mempengaruhi kemungkinan financial distress.

Penelitian Alexanders (2017) dengan judul "Analisis Faktor-Faktor yang Mempengaruhi Kemungkinan terjadinya Financial Distress (Studi Pada Perusahaan Real Estate yang Terdaftar di Bursa Efek Indonesia Periode tahun 2011-2015)”. Hasil analisis hipotesis dan pengujian pada penelitian ini menemukan bahwa secara parsial 
Profit dan Financial Leverage yang diproksikan dengan DER tidak berpengaruh signifikan terhadap prediksi kondisi financial distress pada perusahaan real estate yang terdaftar di Bursa Efek pada tahun 2011-2015, sedangkan variabel Aliran kas, proksi Likuiditas dengan Rasio Lancar, dan Profitabilitas yang disahkan oleh ROA memiliki pengaruh signifikan terhadap prediksi kondisi financial distress pada perusahaan real estate yang terdaftar di BEI pada tahun 2011-2015. Variabilitas variabel dependen (kondisi masalah atau kondisi financial distress) yang dapat dijelaskan oleh variabilitas variabel independen (Laba, Arus Kas, Likuiditas yang diproksi dengan Rasio Lancar, Profitabilitas yang diwakili oleh ROA dan Financial Leverage yang diwakili oleh DER) adalah $61,2 \%$ sementara sisanya, yaitu $38,8 \%$ dijelaskan oleh variabel lain di luar model.

Penelitian Rani (2017) dengan judul "Pengaruh Likuiditas, Leverage, Profitabilitas, Agency Cost dan Sales Growth terhadap Kemungkinan terjadinya Financial Distress (Studi Empiris Pada Perusahaan Manufaktur Yang Terdaftar di Bursa Efek Indonesia Tahun 2012-2015)”. Hasil empiris dari penelitian ini menunjukkan bahwa hanya leverage yang memiliki pengaruh signifikan negatif terhadap kemungkinan kesulitan keuangan. Likuiditas, profitabilitas, biaya agensi dan pertumbuhan penjualan tidak memiliki pengaruh terhadap kemungkinan kesulitan keuangan.

Penelitian Lisiantara dan Febrina (2018) dengan judul "Likuiditas, Leverage, Operating Capacity, Profitabilitas, Sales Growth Sebagai Preditor Financial Distress (Studi Empiris pada Perusahaan Manufaktur Yang Terdaftar di Bursa Efek Indonesia Tahun 2013-2016)". Hasil analisis dari penelitian ini menyatakan bahwa rasio leverage, operating capacity, dan profitabilitas mampu mempengaruhi financial distress, sedangkan rasio likuiditas dan sales growth tidak mampu mempengaruhi financial distress.

Penelitian Ratna et al (2018) dengan judul "Analisis Faktor- Faktor Yang Mempengaruhi Kondisi Financial Distress pada Perusahaan Yang Delisting dari Jakarta Islamic Index Tahun 2012-2016”. Penelitian ini bertujuan untuk menguji faktor yang dapat mempengaruhi kondisi financial distress. Hasil analisis data dengan menggunakan regresi logistic, menyatakan bahwa variabel yang berpengaruh signifikan terhadap financial distress adalah variabel operating capacity yang diproksikan dengan 
total asset turn over yang memiliki pengaruh signifikan dengan tingkat signifikansi < $5 \%$. Sedangkan leverage dan profit margin tidak berpengaruh signifikan terhadap financial distress.

Penelitian Hanifah et al (2013) dengan judul "Pengaruh struktur Corporate Governance dan Financial Indicator terhadap kondisi Financial distress Perusahaan Manufaktur periode 2009-2011. Hasil penelitian ini menunjukkan bahwa ukuran dewan direksi, kepemilikan manajerial, kepemilikan institusional, leverage, dan operating capacity memiliki pengaruh signifikan terhadap kondisi financial distress. Penelitian ini tidak berhasil membuktikan pengaruh ukuran dewan komisaris, komisaris independen, ukuran komite audit, likuiditas, dan profitabilitas terhadap kemungkinan terjadinya financial distress.

Penelitian Triwahyuningtias et al (2012) dengan judul "Analisis Pengaruh Struktur Kepemilikan, Ukuran Dewan, Komisaris Independen, Likuiditas dan Leverage terhadap terjadinya Kondisi Financial Distress (Studi Pada Perusahaan Manufaktur Yang Terdaftar di Bursa Efek Indonesia Tahun 2008-2010)". Hasil penelitian ini menunjukkan bahwa struktur kepemilikan, ukuran direktur, likuiditas dan leverage memiliki dampak yang signifikan terhadap probabilitas perusahaan tertekan keuangan. Bukti pengaruh struktur kepemilikan dan ukuran direktur pada kemungkinan perusahaan mengalami distress financial juga dikonfirmasi oleh tes menggunakan lag 1 tahun. Penelitian ini gagal membuktikan pengaruh ukuran komisaris dan dewan komisaris independen dengan kondisi financial distress.

Penelitian Khaliq et al (2014) dengan judul "Identifying Financial Distress Firms: A Case Study of Malaysia's Government Linked Companies (GLC)". Penelitian ini menilai determinan kesulitan keuangan yang diukur dengan statistik Z Score Model. Lebih jauh, penentu seperti rasio lancar dan rasio utang terbukti. Hasil penelitian menunjukkan bahwa ada hubungan yang signifikan antara variabel rasio lancar dan rasio utang terhadap $Z$ score untuk memprediksi financial distress pada perusahaan yang terdaftar GLC.

Penelitian Mohammed et al (2012) dengan judul “Using Altman's Model and Current Ratio to Assess the Financial Status of Companies Quoted In the Malaysian Stock Exchange". Studi ini menemukan bahwa ada perusahaan tertekan keuangan tercatat di papan utama dan tidak diklasifikasikan sebagai perusahaan PN17. Penelitian 
menyimpulkan bahwa Model Z Score Altman, rasio lancar adalah alat yang berguna bagi investor untuk memprediksi kegagalan keuangan perusahaan.

Penelitian Anggraini (2015) dengan judul "Financial Distress Model Prediction for Indonesian Companies". Berdasarkan hasil analisis data dan pembahasan, dapat disimpulkan bahwa Manajerial Kepemilikan tidak memiliki dampak yang signifikan terhadap financial distress. Namun, Kepemilikan Institusional memiliki dampak yang signifikan terhadap financial distress. Likuiditas sebagai variabel moderasi tidak memiliki pengaruh yang signifikan terhadap pengaruh struktur kepemilikan dengan financial distress.

Penelitian Thim et al (2011) dengan judul "Factors Affecting Financial Distress: The Case Of Malaysian Public Listed Firms". Hasil penelitian menyimpulkan bahwa profitabilitas dan likuiditas berpengaruh negatif signifikan terhadap financial distress, ukuran perusahaan dan risiko berpengaruh negatif tidak signifikan terhadap financial distress, solvabilitas berpengaruh negatif signifikan terhadap financial distress, dan pertumbuhan berpengaruh positif signifikan terhadap financial distress.

Penelitian Masdupi et al (2018) dengan judul "The Influence of Liquidity, Leverage and Profitability on Financial Distress of Listed Manufacturing Companies in Indonesia". Hasil penelitian menunjukkan bahwa (1) likuiditas memiliki pengaruh negatif dan signifikan terhadap financial distress perusahaan manufaktur, (2) leverage berpengaruh negatif dan signifikan terhadap financial distress perusahaan manufaktur, dan (3) profitabilitas memiliki pengaruh negatif dan signifikan terhadap financial distress perusahaan manufaktur yang terdaftar di Bursa Efek Indonesia.

\section{KERANGKA PEMIKIRAN DAN HIPOTESIS}

\section{Pengaruh profitabilitas terhadap financial distress}

Untuk mengukur kemampuan perusahaan dalam memperoleh laba atau keuntungan dapat menggunakan profitabilitas. Profitabilitas ini sering digunakan untuk melihat keadaan perusahaan dalam keadaan baik atau perusahaan sedang bermasalah (financial distress). Perusahaan dalam keadaan baik apabila laba yang diperoleh perusahaan pengalami pertumbuhan dan positif, akan tetapi ketika perusahaan mengalami tekanan keuangan (financial distress) profitabilitas akan turun dari tahun sebelumnya dan mencapai angka negatif. Hal tersebut dibuktikan dengan menurunnya 
tingkat keuntungan akan berpengaruh terhadap keadaan keuangan perusahaan yang semakin menurun dan dapat mengakibatkan financial distress (Andre, 2013).

Hidayat et al (2014) mengemukakan bahwa rasio profitabilitas menunjukkan kemampuan suatu perusahaan dalam mencetak laba. Jika suatu perusahaan mencetak laba yang tinggi, dapat dikatakan agent berhasil dalam pengelolaan perusahaannya. Dengan laba yang tinggi maka juga akan menarik investor untuk berinvestasi, sehingga nantinya akan menjauhkan suatu perusahaan dari ancaman financial distress. Dengan demikian hipotesis yang diajukan:

$\mathrm{H}_{1}$ : Diduga profitabilitas berpengaruh negatif terhadap financial distress.

\section{Pengaruh likuiditas terhadap financial distress}

Rasio likuiditas atau sering disebut juga dengan nama rasio modal kerja, merupakan rasio yang digunakan untuk mengukur seberapa likuidnya suatu perusahaan (Kasmir, 2012:75). Perusahaan dapat dikatakan likuid apabila perusahaan tersebut bisa menyelesaikan kewajiban jangka pendeknya saat jatuh tempo, tetapi apabila perusahaan tidak bisa menyelesaikan kewajiban jangka pendeknya saat jatuh tempo maka perusahaan tersebut dapat dikatakan tidak likuid atau illikuid. Ketika nilai rasio likuiditas tinggi maka perusahaan memiliki kemampuan untuk memenuhi kewajiban hutang jangka pendeknya, sebaliknya jika nilai rasio likuiditasnya rendah maka perusahaan tidak sanggup untuk melunasi hutang jangka pendeknya. Apabila perusahaan dalam kondisi illikuid maka secara otomatis perusahaan akan mengalami kesulitan keuangan atau financial distress.

Almilia dan Kritijadi dalam Triwahyuningtias et al (2012), likuiditas perusahaan menunjukkan kemampuan perusahaan dalam mendanai operasional perusahaan dan melunasi kewajiban jangka pendek perusahaan. Apabila perusahan mampu mendanai dan melunasi kewajiban jangka pendeknya dengan baik maka potensi perusahaan mengalami financial distress akan semakin kecil. Salah satu rasio yang dipakai dalam mengukur likuiditas adalah current ratio (current asset to current liabilities), yang merupakan kemampuan perusahaan memenuhi hutang jangka pendeknya dengan menggunakan aset lancarnya. Hasil penelitian Jiming et al (2011), Triwahyuningtias et al (2012), dan Atika et al (2013), menyimpulkan bahwa likuiditas mampu mempengaruhi financial distress. Dengan demikian hipotesis yang diajukan:

$\mathrm{H}_{2}$ : Diduga likuiditas berpengaruh negatif terhadap financial distress. 


\section{Pengaruh Leverage terhadap financial distress}

Rasio leverage merupakan rasio yang digunakan untuk mengukur seberapa besar hutang yang digunakan dalam pembelanjaan (Sudana, 2009:23). Rasio leverage yang terlalu tinggi menyebabkan perusahaan memiliki tingkat hutang tinggi yang bisa membebani perusahaan pada saat jatuh tempo, sehingga penting bagi perusahaan untuk memperhatikan tingkat leverage agar perusahaan bisa membayar kewajibannya. Apabia perusahaan tidak bisa membayar kewajibannya maka akan sangat mengganggu aktivitas operasional perusahaan dan akan menyebabkan berkurangnya tingkat pendapatan.

Analisis leverage diperlukan untuk mengukur kemampuan perusahaan dalam membayar utang (jangka pendek dan jangka panjang). Apabila suatu perusahaan pembiayaannya lebih banyak menggunakan utang, hal ini berisiko akan terjadi kesulitan pembayaran di masa yang akan datang akibat utang lebih besar dari aset yang dimiliki. Jika keadaan ini tidak dapat diatasi dengan baik, potensi terjadinya financial distress pun semakin besar. Salah satu satu rasio yang dipakai dalam mengukur leverage adalah total liabilities to total ekuitas (Almilia et al, 2013). Dengan demikian hipotesis yang diajukan:

$\mathrm{H}_{3}$ : Diduga leverage berpengaruh positif terhadap financial distress.

\section{Pengaruh Operating Capacity terhadap financial distress}

Operating Capacity menggambarkan terciptanya ketepatan kinerja operasional dari suatu entitas (Jiming dan Weiwei, 2011). Operating Capacity dikenal dengan rasio perputaran total aktiva (total assets turnover ratio), yang dinilai dengan membagi penjualan dengan jumlah aset (operating capacity = penjualan/total aset). Menurut Ardiyanto (2011), peningkatan penjualan yang relatif besar dibandingkan dengan peningkatan aset akan membuat rasio ini semakin tinggi, sebaliknya rasio ini akan semakin rendah jika peningkatan penjualan relatif lebih kecil dari peningkatan aset.

Rasio Aktivitas atau yang sering disebut sebagai operating capacity merupakan rasio yang digunakan untuk menilai efektif atau tidaknya perusahaan dalam menggunakan aset-aset guna menghasilkan penjualan (Atika et al, 2013). Rasio ini dinilai dari total asset turnover ratio (TATO), dimana total penjualan dibagi dengan jumlah aset yang dimiliki perusahaan. Mengacu pada penelitian yang dilakukan oleh (Hanifah et al, 2013; Simanjuntak et al, 2017; Widhiari et al, 2015) menunjukkan bahwa operating capacity berpengaruh terhadap financial distress. Pihak lain menunjukkan 
bahwa hasil penelitian operating capacity tidak berpengaruh terhadap financial distress (Yustika, 2015). Dengan demikian hipotesis yang diajukan:

$\mathrm{H}_{4}$ : Diduga operating capacity berpengaruh negatif terhadap financial distress.

\section{Pengaruh Sales Growth terhadap financial distress}

Pertumbuhan penjualan (sales growth) adalah rasio yang digunakan untuk memprediksi pertumbuhan perusahaan dimasa yang akan datang dari penerimaan yang dihasilkan atas produk maupun jasa, serta pendapatan yang dihasilkan dengan adanya penjualan. Pertumbuhan penjualan (sales growth) mencerminkan penerapan keberhasilan investasi perusahaan pada periode yang lalu dan dapat dijadikan sebagai prediksi untuk pertumbuhan perusahaan di masa depan. Pattinasarany (2010) menjelaskan bahwa rasio sales growth digunakan untuk mengukur tingkat pertumbuhan penjualan pada suatu periode. Rasio sales growth dihitung dengan cara mengurangi sales periode sekarang dengan periode sebelumnya, kemudian dibagi dengan sales periode sebelumnya.

Sales growth dapat menjadi ukuran dari keberhasilan investasi yang terjadi pada periode lalu, sehingga dapat dijadikan prediksi pertumbuhan perusahaan di masa yang akan datang. Sales growth dapat mempengaruhi keuntungan yang dimiliki perusahaan di masa yang akan datang. Sales growth yang tinggi dapat meningkatkan pendapatan perusahaan dari hasil penjualan yang terjadi selama periode tertentu pada perusahaan tersebut. Hal tersebut menjadi sinyal bagi investor maupun kreditur karena sales growth perusahaan yang tinggi maka akan mempengaruhi aset dan laba perusahaan, sehingga investor dan kreditur tertarik untuk memberikan investasi dan kredit kepada perusahaan. Sales growth menunjukkan angka yang rendah dapat menyebabkan perusahaan mengalami kondisi financial distress karena penjualan yang turun dari periode lalu sehingga dapat mempengaruhi aset, laba, dan hutang perusahaan.

Berdasarkan penelitian sales growth terhadap financial distress yang dilakukan oleh Widhiari et al (2015) menunjukkan pertumbuhan penjualan berpengaruh terhadap financial distress. Lain halnya dengan penelitian (Simanjuntak et al, 2017; Liana et al (2014) yang berpendapat bahwa sales growth tidak signifikan terhadap financial distress ini berarti tidak adanya pengaruh sales growth terhadap financial distress. Dengan demikian hipotesis yang diajukan:

$\mathrm{H}_{5}$ : Diduga sales growth berpengaruh negatif terhadap financial distress. 


\section{METODE PENELITIAN}

Objek yang diteliti adalah perusahaan pertambangan yang terdaftar di Bursa Efek Indonesia tahun 2015-2017. Populasi dalam penelitian ini sebanyak 41 perusahaan pertambangan yang terdaftar di Bursa Efek Indonesia, Adapun sampel ditentukan sebanyak 32 perusahaan pertambangan yang terdaftar di Bursa Efek Indonesia periode 2015-2017. Analisis data yang digunakan dalam penelitian ini adalah statistik deskriptif, uji asumsi klasik, pemilihan model, analisis regresi linier berganda, koefisien determinasi $\left(\mathrm{r}^{2}\right)$ dan uji hipotesis.

\section{ANALISIS DATA}

\section{Uji Asumsi Klasik}

Uji Normalitas

Pada pengujian ini normalitas, dari hasil yang didapatkan bahwa nilai probabilitas sebesar 0,397249. Dengan demikian dapat dikatakan bahwa data normal karena probabilitas jarque-bera $(0,397249)>0,05$.

\section{Uji Multikolinearitas}

Hasil uji multikolinearitas, terlihat bahwa tidak ada koefisien korelasi antar variabel yang lebih besar dari 0,80 atau mendekati 1 . Dengan demikian tidak terjadi adanya multikolinearitas antar variabel pada penelitian ini.

\section{Uji Heteroskedastisitas}

Hasil uji heteroskedastisitas, diperoleh nilai probabilitas Chi-Square sebesar 0,0756. Hasil ini menunjukkan bahwa nilai probabilitas Chi-Square lebih besar dari 0,05, maka dapat disimpulkan tidak terdapat heteroskedastisitas pada data.

\section{Uji Autokorelasi}

Hasil uji autokorelasi, diperoleh hasil Durbin-Watson statistik (DW stat) yaitu sebesar 2,142415. Selanjutnya dibandingkan nilai DW stat dengan DW tabel yang terdiri dari dua nilai yaitu batas bawah (dL) dan batas atas (dU). Dengan $k=5$ karena jumlah variabel bebas yang digunakan sebanyak 5 dan $\mathrm{n}=96$, maka didapatkan pada tabel Durbin Watson $(\alpha=5 \%$ ) batas dL yaitu 1,5600 dan dU yaitu 1,7785. Maka dapat dinyatakan bahwa hasil dari uji statistik Durbin-Watson berada pada daerah $\mathrm{dU} \leq \mathrm{d} \leq 4$ $\mathrm{dU}$ atau $1,7785 \leq 2,142415 \leq 2,2215$ sehingga dapat diputuskan bahwa tidak terdapat autokorelasi. 


\section{Pemilihan Model}

Uji model data panel dalam menentukan model yang tepat pada setiap persamaan. Dalam menentukan pemilihan model yang tepat, maka akan dilakukan Chow Test, Hausman test dan Lagrange Multiplier Test. Berdasarkan hasil pengujian berpasangan yang dilakukan, maka dapat disimpulkan:

Tabel 1.

\section{Kesimpulan Pengujian Model Regresi Data Panel}

\begin{tabular}{|c|c|c|c|}
\hline Metode & Pengujian & Hasil & Kesimpulan \\
\hline Chow Test & $\begin{array}{l}\text { Common Effect vs } \\
\text { Fixed Effect }\end{array}$ & $\begin{array}{ll}\text { Fixed } & \text { Effect } \\
\text { Model } & \end{array}$ & $\begin{array}{c}\text { Random } \\
\text { Effect }\end{array}$ \\
\hline $\begin{array}{l}\text { Hausmann } \\
\text { Test }\end{array}$ & $\begin{array}{lrl}\text { Fixed Effect } & \text { vs } \\
\text { Random Effect } & \end{array}$ & $\begin{array}{l}\text { Random Effect } \\
\text { Model }\end{array}$ & $\begin{array}{l}\text { Model } \\
\text { (REM) }\end{array}$ \\
\hline $\begin{array}{l}\text { Lagrange } \\
\text { Multiplier }\end{array}$ & $\begin{array}{l}\text { Common Effect vs } \\
\text { Random Effect }\end{array}$ & $\begin{array}{l}\text { Random Effect } \\
\text { Model }\end{array}$ & \\
\hline
\end{tabular}

Dari hasil pengujian model regresi data panel di atas, didapatkan hasil yang merekomendasikan penggunaan model Random Effect Model yang akan dianalisis lebih lanjut dalam penelitian ini. Model Random Effect Model lebih baik digunakan pada data panel apabila jumlah individu lebih besar daripada jumlah kurun waktu yang ada.

\section{Analisis Random Effect Model}

Model ini berasumsi akan selalu ada dan akan mungkin berkorelasi sepanjang time series dan cross section. Model ini digunakan untuk mengatasi kelemahan model fixed effect yang menggunakan variabel dummy. Dibawah ini merupakan hasil olah data dengan Eviews 8.0 dengan Random Effect Model sebagai berikut:

Tabel 2.

\section{Hasil Analisis Random Effect Model}

Dependent Variable: FINANCIALDISTRESS

Method: Panel EGLS (Cross-section random effects)

Periods included: 3

Cross-sections included: 32

Total panel (balanced) observations: 96

Swamy and Arora estimator of component variances

\begin{tabular}{ccccc}
\hline \hline Variable & Coefficient & Std. Error & t-Statistic & Prob. \\
\hline \hline PROF_ & -0.056832 & 0.008944 & -6.354409 & 0.0000 \\
LIKUID_ & -0.006263 & 0.001127 & -5.556319 & 0.0000 \\
LEV_ & -0.014752 & 0.040613 & -0.363231 & 0.7173 \\
OC_ & -2.459806 & 0.408482 & -6.021829 & 0.0000 \\
SG_ & -0.000608 & 0.002520 & -0.241097 & 0.8100 \\
C & 0.804662 & 0.362718 & 2.218422 & 0.0290 \\
\hline \hline
\end{tabular}

Sumber : Data Sekunder diolah dengan Eviews 8.0 
Analisis Regresi Linier Berganda

Untuk menganalisis pengaruh profitabilitas, likuiditas, leverage, operating capacity dan sales growth terhadap financial distress pada Perusahaan Pertambangan yang Terdaftar di Bursa Efek Indonesia tahun 2015-2017, maka penulis menggunakan teknik analisis regresi data panel. Berdasarkan Tabel 2., diperoleh bentuk persamaan sebagai berikut:

\section{$Y=0.804662-0.056832$ PROF -0.006263 LIKUID -0.014752 LEV -2.459806 OC -0.000608 SG}

Berdasarkan persamaan di atas, maka dapat diinterpretasikan sebagai berikut:

1. Koefisien konstanta a sebesar 0,804662 artinya jika profitabilitas, likuiditas, leverage, operating capacity dan sales growth konstan, maka financial distress sebesar 0,804662 .

2. Koefisien regresi $b_{1}$ variabel profitabilitas $\left(X_{1}\right)$ sebesar $-0,056832$, artinya jika profitabilitas meningkat sebesar 1\%, maka financial distress mengalami penurunan sebesar 0,056832\% dengan asumsi variabel bebas lainnya konstan.

3. Koefisien regresi $b_{2}$ variabel likuiditas $\left(X_{2}\right)$ sebesar $-0,006263$, artinya jika likuiditas meningkat sebesar 1\%, maka financial distress mengalami penurunan sebesar $0,006263 \%$ dengan asumsi variabel bebas lainnya konstan.

4. Koefisien regresi $b_{3}$ variabel leverage $\left(\mathrm{X}_{3}\right)$ sebesar $-0,014752$, artinya jika leverage meningkat sebesar 1\%, maka financial distress mengalami penurunan sebesar 0,014752\% dengan asumsi variabel bebas lainnya konstan.

5. Koefisien regresi $\mathrm{b}_{4}$ variabel Operating Capacity $\left(\mathrm{X}_{4}\right)$ sebesar $-2,459806$, artinya jika operating capacity meningkat sebesar 1\%, maka financial distress mengalami penurunan sebesar 2,459806\% dengan asumsi variabel bebas lainnya konstan.

6. Koefisien regresi $b_{5}$ variabel Sales Growth $\left(\mathrm{X}_{5}\right)$ sebesar $-0,000608$, artinya jika Sales Growth meningkat sebesar $1 \%$, maka financial distress mengalami penurunan sebesar 2,000608\% dengan asumsi variabel bebas lainnya konstan.

\section{Analisis Koefisien Determinasi $\left(\mathbf{R}^{2}\right)$}

Penggunaan nilai koefisien determinasi adalah untuk mengetahui besarnya pengaruh profitabilitas, likuiditas, leverage, operating capacity dan sales growth 
terhadap financial distress. Hasil analisis koefisien determinasi yang disajikan pada Tabel 4.22. menunjukkan bahwa Adjusted $R^{2}=0,661627$, ini dapat ditafsirkan bahwa 66,16\% dari Financial Distress dapat dijelaskan oleh profitabilitas, likuiditas, leverage, operating capacity dan sales growth, sedangkan sisanya sebesar 33,84\% Financial Distress dipengaruhi oleh variabel lain yang tidak digunakan pada penelitian ini.

\section{Uji Hipotesis (Uji t)}

Tujuan dari uji t adalah untuk mengetahui apakah secara parsial variabel independen berpengaruh signifikan terhadap variabel dependen. Uji ini dilakukan untuk memeriksa lebih lanjut variabel independen manakah yang berpengaruh signifikan terhadap financial distress pada Perusahaan Pertambangan yang Terdaftar di Bursa Efek Indonesia tahun 2015-2017. Pengambilan keputusan uji t dapat didasarkan dengan melihat nilai signifikansi, yaitu nilai signifikan $\mathrm{t}<\alpha$ (5\%), Maka Ho ditolak dan sebaliknya. Berdasarkan hasil pengolahan data, diperoleh hasil perhitungan uji t dapat dilihat pada Tabel 3. di bawah ini:

\section{Tabel 3.}

\section{Hasil Uji Hipotesis}

\begin{tabular}{|c|l|c|c|c|}
\hline No. & \multicolumn{1}{|c|}{ Variabel } & Coefficient & Signifikansi & Keputusan \\
\hline 1. & $\begin{array}{l}\text { Profitabilitas } \\
\left(\mathrm{X}_{1}\right)\end{array}$ & -0.056832 & 0.0000 & $\mathrm{Ha}_{1}$ diterima \\
\hline 2. & $\begin{array}{l}\text { Likuiditas } \\
\left(\mathrm{X}_{2}\right)\end{array}$ & -0.006263 & 0.0000 & $\mathrm{Ha}_{2}$ diterima \\
\hline 3. & Leverage $\left(\mathrm{X}_{3}\right)$ & -0.014752 & 0.7173 & $\mathrm{Ha}_{3}$ ditolak \\
\hline 4. & $\begin{array}{l}\text { Operating } \\
\text { Capacity }\left(\mathrm{X}_{4}\right)\end{array}$ & -2.459806 & 0.0000 & $\mathrm{Ha}_{4}$ diterima \\
\hline 5. & $\begin{array}{l}\text { Sales Growth } \\
\left(\mathrm{X}_{5}\right)\end{array}$ & -0.000608 & 0.8100 & $\mathrm{Ha}_{5}$ ditolak \\
\hline \multicolumn{4}{|c|}{ Sumber: Hasil Pengolahan data Eviews 8.0}
\end{tabular}

Berdasarkan Tabel 3. di atas, maka hasil pengujian hipotesis adalah sebagai berikut:

1. Variabel profitabilitas memiliki nilai signifikansi sebesar $0,0000 \leq 0,05$ dengan nilai $\beta_{1}$ sebesar -0,056832 (Negatif). Dengan demikian, $\mathrm{Ha}_{1}$ yang menyatakan bahwa "Profitabilitas berpengaruh negatif terhadap financial distress pada Perusahaan Pertambangan yang Terdaftar di Bursa Efek Indonesia tahun 2015-2017” diterima.

2. Variabel likuiditas memiliki nilai signifikansi sebesar $0,0000 \leq 0,05$ dengan nilai $\beta_{2}$ sebesar -0,006263 (Negatif). Dengan demikian, $\mathrm{Ha}_{2}$ yang menyatakan bahwa "Likuiditas berpengaruh negatif terhadap financial distress pada Perusahaan Pertambangan yang Terdaftar di Bursa Efek Indonesia tahun 2015-2017” diterima. 
3. Variabel Leverage memiliki nilai signifikansi sebesar $0,7173>0,05$ dengan nilai $\beta_{3}$ sebesar -0.014752 (Negatif). Dengan demikian, $\mathrm{Ha}_{3}$ yang menyatakan bahwa "Leverage berpengaruh positif terhadap financial distress pada Perusahaan Pertambangan yang Terdaftar di Bursa Efek Indonesia tahun 2015-2017" ditolak.

4. Variabel operating capacity memiliki nilai signifikansi sebesar $0,0000 \leq 0,05$ dengan nilai $\beta_{4}$ sebesar -2.459806 (Negatif). Dengan demikian, Ha $\mathrm{Ha}_{4}$ yang menyatakan bahwa “Operating capacity berpengaruh negatif terhadap financial distress pada Perusahaan Pertambangan yang Terdaftar di Bursa Efek Indonesia tahun 2015-2017” diterima.

5. Variabel Sales Growth memiliki nilai signifikansi sebesar 0,8100>0,05 dengan nilai $\beta_{5}$ sebesar -0.000608 (Negatif). Dengan demikian, $\mathrm{Ha}_{5}$ yang menyatakan bahwa "Sales Growth berpengaruh negatif terhadap financial distress pada Perusahaan Pertambangan yang Terdaftar di Bursa Efek Indonesia tahun 2015-2017” ditolak.

\section{PEMBAHASAN}

\section{Pengaruh Profitabilitas terhadap Financial Distress}

Hasil penelitian menyimpulkan bahwa profitabilitas berpengaruh negatif terhadap Financial Distress. Rasio profitabilitas perusahaan yang tinggi menunjukkan bahwa pengembalian investasi dari aset perusahaan sangat baik. Laba yang dihasilkan perusahaan cukup untuk mendanai operasional perusahaan dan mampu mengembalikan investasi dari investor. Hal ini juga menunjukkan bahwa kondisi keuangan perusahaan dalam keadaan yang baik dan jauh dari kondisi financial distress. Semakin meningkatnya keuntungan yang dicapai perusahaan, maka akan menunjukkan kinerja keuangan perusahaan semakin baik sehingga dengan begitu perusahaan akan semakin jauh dari kondisi financial distress.

Hal ini mencerminkan bahwa penting bagi perusahan pertambangan untuk meningkatkan profitabilitas dalam upaya mengatasi kesulitan keuangan (Financial distress) dimasa mendatang. Analisa financial distress berdasarkan altman Z-score, menemukan bahwa terdapat $53,13 \%$ data yang diobservasi berada pada posisi bangkrut. Berdasarkan data yang diperoleh, menunjukkan bukti empiris seperti pada PT. Bayan Resources Tbk, PT. Tambang Batubara Bukit Asam Tbk dan PT. SMR Utama Tbk, dimana perusahaan pada tahun 2015 berada pada kategori bangkrut dan rawan bangkrut, kemudian mengalami perbaikan pada tahun 2017 menjadi kategori tidak bangkrut, menunjukkan bahwa jika perusahaan pertambangan dapat mencetak profitabilitas yang 
tinggi, maka hal tersebut akan menarik investor untuk berinvestasi, sehingga nantinya akan menjauhkan suatu perusahaan dari ancaman financial distress.

Hasil penelitian ini sejalan dengan penelitian yang dilakukan oleh Yustika (2015), Alexanders (2017), Thim et al (2011) serta Masdupi et al (2018) yang menyimpulkan bahwa profitabilitas berpengaruh negatif signifikan terhadap Financial Distress.

\section{Pengaruh Likuiditas terhadap Financial Distress}

Hasil penelitian menyimpulkan bahwa likuiditas berpengaruh negatif terhadap Financial Distress. Perusahaan yang memiliki rasio likuiditas tinggi maka memiliki kemampuan untuk memenuhi kewajiban jangka pendek dengan aset lancar yang dimilikinya. Itu membuktikan bahwa kondisi keuangan perusahaan masih baik baik saja sehingga mampu untuk melunasi kewajiban jangka pendek yang telah jatuh tempo. Dengan demikian, tingkat likuiditas yang tinggi akan menurunkan tingkat kemungkinan terjadinya financial distress diperusahaan.

Hal ini menunjukkan bahwa perusahaan pertambangan dengan likuiditas tinggi maka perusahaan mampu menyelesaikan kewajiban jangka pendeknya saat jatuh tempo dari aset yang dimiliki, yang secara otomatis perusahaan tidak mengalami kesulitan keuangan (financial distress). Mayoritas perusahaan sampel penelitian berdasarkan altman Z-score, mengalami kesulitan keuangan (financial distress). Data penelitian diperoleh hasil bahwasanya terdapat beberapa perusahaan yang memiliki nilai likuiditas tinggi namun perusahaan tersebut mengalami kondisi financial distress seperti pada PT. Delta Dunia Makmur Tbk, PT. Petrosea Tbk, PT. Ratu Prabu Energi Tbk, PT. Medco Energi Internasional Tbk dan PT. Mitra Investindo Tbk. Likuiditas perusahaan pertambangan yang terlalu tinggi akan mengakibatkan profit yang dicapai akan rendah. Hal ini disebabkan banyak uang tunai yang menganggur sehingga kurang produktif atau tingginya persediaan yang dimiliki perusahaan menandakan penjualan perusahaan rendah. Namun, mayoritas perusahaan mengalami financial distress memiliki likuiditas rendah. Jika likuiditas terlalu rendah akan mempengaruhi kepercayaan dari pihak eksternal maupun internal. Pihak internal seperti gaji karyawan yang tidak dapat dibayarkan dengan tepat waktu. Sedangkan dampak bagi pihak eksternal misalnya bagi supplier. Jika seringkali terjadi keterlambatan pembayaran, maka hal tersebut dapat mempengaruhi kepercayaan pihak supplier terhadap perusahaan. 
Hasil penelitian ini sejalan dengan penelitian yang dilakukan oleh Widhiari et al (2015), Yustika (2015), Hidayat et al (2014), Alexanders (2017), Triwahyuningtias et al (2012), Mohammed et al (2012), Thim et al (2011) serta Masdupi et al (2018) yang menyimpulkan bahwa likuiditas berpengaruh negatif signifikan terhadap Financial Distress.

\section{Pengaruh Leverage terhadap Financial Distress}

Hasil penelitian menyimpulkan bahwa leverage tidak berpengaruh positif terhadap Financial Distress. Hal ini mencerminkan bahwa keputusan dalam menggunakan dana pihak ketiga diserahkan kepada agent karena telah diberikan wewenang untuk mengelola dan mengambil keputusan atas perusahaan. Penggunaan dana pihak ketiga yang besar akan menyebabkan munculnya kewajiban dengan jumlah besar pula yang harus di bayar perusahaan di masa yang akan datang, apabila keadaan seperti ini tidak diatasi dengan baik, maka kemungkinan perusahaan mengalami financial distress akan semakin besar. Dengan demikian, perusahaan masih dapat menjaga tingkat hutang dan mampu mengantisipasi risiko yang ditimbulkan dari hutang yang dilakukan.

Data penelitian diperoleh hasil bahwasanya terdapat beberapa perusahaan yang memiliki nilai leverage tinggi namun perusahaan tersebut mengalami perbaikan nilai ZScore yang berarti perusahaan dapat terhindar dari kondisi financial distress seperti pada PT. Adaro Energy, Tbk, PT. Bara Jaya Internasional Tbk, PT. Bayan Resources Tbk dan PT. Delta Dunia Makmur Tbk. Tingkat leverage perusahaan pertambangan, belum mampu menghindari kondisi kesulitan keuangan (Financial Distress). Hal ini mencerminkan kondisi bahwa jika perusahaan pertambangan lebih mengandalkan hutang untuk membiayai kegiatan operasionalnya, maka perusahaan berisiko akan terjadi kesulitan pembayaran di masa yang akan datang akibat hutang tersebut. Namun, jika dapat diatasi dengan baik dan masih dalam kondisi wajar, potensi terjadinya financial distress dapat dihindari.

Hasil penelitian ini sejalan dengan penelitian yang dilakukan oleh Widhiari et al (2015), Alexanders (2017) serta Ratna et al (2018) yang menyimpulkan bahwa Leverage tidak berpengaruh signifikan terhadap Financial Distress. 


\section{Pengaruh Operating Capacity terhadap Financial Distress}

Hasil penelitian menyimpulkan bahwa operating capacity berpengaruh negatif terhadap Financial Distress. Hal ini menunjukkan bahwa tingginya tingkat penjualan perusahaan dengan memanfaatkan asset yang dimiliki dalam kegiatan operasional perusahaan, mampu menurunkan kemungkinan perusahaan dalam kondisi financial distress. Atau dengan kata lain, jika penjualan perusahaan semakin rendah yang diakibatkan dengan penggunaan aset yang tidak efektif untuk kegiatan operasional, maka perusahaan akan rentan terhadap kondisi financial distress.

Kemampuan perusahaan pertambangan dalam memanfaatkan asetnya secara efektif untuk menghasilkan penjualan dapat menurunkan tingkat kesulitan keuangan (financial distress) perusahaan. Data penelitian diperoleh hasil bahwasanya terdapat beberapa perusahaan yang memiliki nilai operating capacity tinggi dan perusahaan tersebut mengalami perbaikan nilai Z-Score yang berarti perusahaan dapat terhindar dari kondisi financial distress seperti pada PT. Bayan Resources Tbk, PT. Delta Dunia Makmur Tbk dan PT. SMR Utama Tbk. Semakin tinggi tingkat aktivitas perusahaan yang digambarkan dengan tingginya total asset turnover, maka semakin kecil tingkat financial distress perusahaan. Hal tersebut juga menyokong pertumbuhan laba yang mengakibatkan perusahaan pertambangan dapat terhindar dari risiko financial distress.

Hasil penelitian ini sejalan dengan penelitian yang dilakukan oleh Widhiari et al (2015), Hidayat et al (2014), Ratna et al (2018) serta Hanifah et al (2013) yang menyimpulkan bahwa operating capacity berpengaruh negatif signifikan terhadap Financial Distress.

\section{Pengaruh Sales Growth terhadap Financial Distress}

Hasil penelitian menyimpulkan bahwa sales growth tidak berpengaruh negatif terhadap Financial Distress. Sales growth atau rasio pertumbuhan penjualan merupakan rasio yang digunakan untuk memprediksi suatu pertumbuhan perusahaan dalam masa yang akan datang, rasio ini juga mencerminkan tentang penerapan keberhasilan investasi yang dilakukan perusahaan pada periode yang lalu yang dapat dijadikan sebagai prediksi mengenai pertumbuhan perusahaan dalam periode yang akan datang. Berhubungan dengan teori keagenan yaitu kegiatan operasional yang dilakukan perusahaan merupakan tugas yang dipertangungjawabkan oleh agent, apabila sales growth meningkat maka menunjukkan pengelolaan agent yang baik. Dengan demikian, 
meskipun sales growth tinggi jika diikuti dengan beban yang tinggi dalam kegiatan operasional memperoleh penjualan tersebut, maka kondisi ini secara langsung tidak menurunkan kemungkinan perusahaan mengalami Financial Distress.

Peningkatan pertumbuhan penjualan perusahaan pertambangan, belum mampu menghindari kondisi kesulitan keuangan (Financial Distress) secara signifikan. Data penelitian diperoleh hasil bahwasanya terdapat beberapa perusahaan yang memiliki nilai Sales growth positif namun perusahaan tersebut mengalami kondisi financial distress seperti pada PT. Bara Jaya Internasional Tbk, PT. Borneo Lumbung Energi \& Metal Tbk, PT. Delta Dunia Makmur Tbk dan PT. Golden Eagle Energy Tbk. Hal ini dapat dikarenakan banyaknya perusahaan pertambangan yang mengalami pertumbuhan penjualan negatif. Ini berarti, tingkat sales growth perusahaan tidak dapat memperlihatkan apakah perusahaan sedang dalam kondisi financial distress atau tidak. Selain itu, tingginya sales growth perusahaan pertambangan jika diikuti dengan beban yang tinggi untuk memperoleh penjualan tersebut, maka peningkatan penjualan tersebut tidak diikuti dengan pertumbuhan laba sehingga tidak mampu menghindari kesulitan keuangan (financial distress) perusahaan pertambangan.

Hasil penelitian ini sejalan dengan penelitian yang dilakukan oleh Rani (2017) serta Lisiantara dan Febrina (2018) yang menyimpulkan bahwa sales growth tidak berpengaruh negatif signifikan terhadap Financial Distress.

\section{SIMPULAN DAN SARAN}

\subsection{Simpulan}

Berdasarkan uraian hasil penelitian pada bab sebelumnya, maka dapat disimpulkan bahwa :

1. Profitabilitas berpengaruh negatif terhadap financial distress, yang berarti semakin tinggi profitabilitas yang dicapai perusahaan menunjukkan kinerja keuangan perusahaan semakin baik sehingga perusahaan akan semakin jauh dari kondisi financial distress.

2. Likuiditas berpengaruh negatif terhadap financial distress, yang berarti perusahaan dengan likuiditas tinggi menunjukkan perusahaan memiliki kemampuan untuk memenuhi kewajiban jangka pendek dengan aset lancar yang dimilikinya sehingga tingkat likuiditas yang tinggi akan menurunkan kemungkinan terjadinya kondisi financial distress. 
3. Leverage tidak berpengaruh positif terhadap financial distress, yang berarti tingginya tingkat leverage perusahaan tidak menjadikan perusahaan mengalami financial distress. Dengan demikian, perusahaan masih dapat menjaga tingkat hutang dan mampu mengantisipasi risiko yang ditimbulkan dari hutang yang dilakukan.

4. Operating Capacity berpengaruh negatif terhadap financial distress, yang berarti kemampuan perusahaan pertambangan dalam memanfaatkan asetnya secara efektif untuk menghasilkan penjualan dapat menghindarkan perusahaan tingkat kesulitan keuangan (financial distress).

5. Sales Growth tidak berpengaruh negatif terhadap financial distress, yang berarti peningkatan pertumbuhan penjualan perusahaan pertambangan, belum mampu menghindari kondisi kesulitan keuangan (Financial Distress) secara signifikan. Hal ini dapat dikarenakan meskipun sales growth tinggi, jika diikuti dengan beban yang tinggi dalam kegiatan operasional perusahaan untuk memperoleh penjualan tersebut, maka kondisi ini belum mampu menurunkan kemungkinan perusahaan mengalami Financial Distress.

\subsection{Saran}

Peneliti merekomendasikan saran berdasarkan kesimpulan hasil penelitian sebagai berikut:

1. Bagi pihak manajemen perusahaan pertambangan, terlebih perusahaan yang diprediksi mengalami kebangkrutan dapat digunakan sebagai dasar untuk melakukan tindakan-tindakan perbaikan yang tepat untuk mengatasi kondisi financial distress, yaitu dengan meningkatkan profitabilitas, likuiditas serta operating capacity yang dimiliki untuk menurunkan tingkat financial distress perusahaan dimasa mendatang.

2. Bagi investor, informasi tersebut dapat membantu pengambilan keputusan, apakah akan membeli melakukan investasi dengan membeli saham atau menjual saham yang sudah dimiliki dengan menganalisis lebih dalam kondisi keuangan perusahaan serta upaya-upaya perusahaan untuk meningkatkan kinerja keuangan perusahaan.

3. Bagi peneliti berikutnya

Adapun saran yang dapat diberikan bagi peneliti berikutnya adalah sampel penelitian lebih baik jika diambil dari perusahaan diluar perusahaan pertambangan yang Terdaftar di BEI sehingga memberikan gambaran yang lebih spesisfik dan 
mendalam mengenai faktor yang mempengaruhi kondisi Financial Distress pada perusahaan go public. Disamping itu perlu untuk memperpanjang periode penelitian guna lebih baik akan meningkatkan keakuratan data penelitian sehingga diperoleh estimasi yang lebih representatif.

\section{DAFTAR PUSTAKA}

Adi, Suyatmin Waskito dan Aryani Intan Endah Rahmawati. 2015. Analisis Rasio Keuangan terhadap Kondisi Financial Distress pada Perusahaan Manufaktur yang terdaftar di Bursa Efek INDONESIA Tahun 2008-2013. Seminar Nasional dan The 2nd Call for Syariah Paper Menakar Masa Depan Profesi Memasuki MEA 2015 Menuju Era Crypto Economic ISSN 2460-0784.

Aghaei, M., Kazemi, A., Moezzi, A.D., Rajabian, M., Beigi, M. Asadollahi, A. 2013. Financial Distress and Bankruptcy Prediction in Subsidiaries of the Largest Business Holding in Iran Using the Model of Altman. Research Journal of Recent Sciences, Vol 2,No 8, Hal 40-46.

Alexanders, Miechael. 2017. Analisis Faktor-Faktor yang Mempengaruhi Kemungkinan terjadinya Financial Distress (Studi Pada Perusahaan Real Estate Yang Terdaftar Di Bursa Efek Indonesia Periode tahun 2011-2015). JOM Fekon, Vol. 4 No. 2 (Oktober) 2017.

Almilia, Luciana Spica \& Kristijadi. 2013. Analisis Rasio Keuangan Untuk Memprediksi Kondisi Financial Distress Perusahaan Manufaktur Yang Terdaftar di Bursa Efek Jakarta. JAAI Volume 7 No. 2, Desember 2013, ISSN: 1410 2420 .

Ambarwati, Indah Eva dan Daniel Sugama Stephanus. 2014. Struktur Kepemilikan, Kebijakan Dividen, dan Leverage sebagai Determinan atas Nilai Perusahaan. Jurnal Akuntansi Multiparadigma. Volume 5 No. 2. Hal. 170-183.

Anastasia et all. 2014. Account Receivable Management and Corpprate Perfomance of Companies in the Food \& Beverage Industri : Evidence From Nigeria. European Journal of Accounting Auditing and Finance Research. Vol. 2, No.10, pp. 34-47.

Andre, Orina. 2013. Pengaruh Profitabilitas, Likuiditas, dan Leverage dalam Memprediksi Financial Distress pada Perusahaan Aneka Industri yang Terdaftar di BEI. Journal UNP. 
Anggraini, Dewi. 2015. Financial Distress Model Prediction for Indonesian Companies. International Journal of Management and Administrative Sciences (IJMAS), ISSN: 2225-7225, Vol. 3, No. 04, (74-84).

Ardiyanto, Feri Dwi. 2011. Prediksi Rasio Keuangan terhadap Kondisi Financial Distress Perusahaan Manufaktur yang Terdaftar di BEI. Semarang: Fakultas Ekonomi Universitas Diponegoro.

Atika, dkk. 2013. Pengaruh Beberapa Rasio Keuangan terhadap Prediksi Kondisi Financial Distress. Jurnal Administrasi Bisnis Vol 1, No 2.

Baimwera, B., \& Muriuki, A. M. 2014. Analysis of Corporate Financial Distress Determinants: a Survey of Non-Financial Firms Listed in the Nse. International Journal of Current Business and Social Sciences, 1(2), 58-80.

Bhattacharyya, Debarshi. 2012. Financial Statement Analysis Noida: Dorling Kimsdey. Licencess Of Pearon Education In Sourth Asia.

Celli, Massimiliano. 2015. Can Z-Score Model Predict Listed Companies' Failures in Italy? An Empirical Test. International Journal of Business and Management; Vol. 10, No. 3; 2015, ISSN 1833-3850 E-ISSN 1833-8119.

Danovi, A., \& Quagli, A. 2012. Crisi Aziendali e Processi di Risanamento. (pp.154167). Ipsoa, Milano.

Diratama, Ichsan. 2018. Analisis Prediksi Kebangkrutan pada Perusahaan Pertambangan yang Terdaftar di bursa Efek Indonesia Tahun 2014-2016. Jurnal Akuntansi Fakultas Ekonomi Universitas Negeri Padang.

Endri. 2009. Prediksi Kebangkrutan Bank untuk Menghadapi dan Mengelola Perubahan Lingkungan bisnis: Analisis Model Altman's Z-Score. Perbanas Quarterly Review, vol.2, no.1.

Fahmi, Irham. 2012. Pengantar Pasar Modal. Edisi Pertama. Bandung : Alfabeta.

Fathuddin, Fahmy. 2012. Prediksi Kebangkrutan Pada Perusahaan Pertambangan yang Go Public di Jakarta Islamic Index Tahun 2005-2006. Fakultas Syari’ah. Universitas Islam Negeri Sunan Kalijaga.

Firmansyah, Amrie dan Ferry Irawan. (2017). Pengaruh Adobsi IFRS dan Corporate Governance terhadap Kualitas Informasi Akuntansi di Indonesia. SNAB Universitas Widyatama. 
Ghozali, Imam. 2013. Analisis Multivariat dan Ekonometrika : Teori, Konsep, dan Aplikasi dengan Eviews 8. Semarang: Badan Penerbit Universitas Diponegoro.

Gujarati, D.N. 2012. Dasar-dasar Ekonometrika. Terjemahan Mangunsong, R.C., buku 2. Edisi 5. Jakarta: Salemba Empat.

Hanafi, Mamduh H dan A. Halim. 2017. Analisis Laporan Keuangan. Edisi 3. Yogyakarta : Penerbit UPP STIM YKPN.

Hanifah, Oktita Earning dan Purwanto, Agus. 2013. Pengaruh struktur Corporate Governance dan Financial Indicator terhadap kondisi Financial distress Perusahaan Manufaktur periode 2009-2011. Jurnal of accounting, Vol. 2, No. 2, Hal 1, ISSN (online) : 2337-3806.

Harahap, Sofyan Syafri. 2011. Analisis Kritis Atas Laporan Keuangan. Jakarta: Rajawali Press.

Hartono, Jogiyanto. 2011. Metodologi Penelitian Bisnis: Salah Kaprah dan Pengalaman-pengalaman. Yogyakarta: BPFE.

Hartono, Jogiyanto. 2013. Teori Portofolio dan Analisis Investasi. Edisi Kedelapan. Yogyakarta: BPFE.

Hery. 2015. Analisis Laporan Keuangan. Edisi 1. Yogyakarta: Center For Academic Publishing Services.

Hidayat., Muhammad Arif dan Wahyu Meiranto. 2014. Prediksi Financial Distress Perusahaan Manufaktur di Indonesia. Diponegoro Journal of Accounting Volume 3, Nomor 3, Tahun 2014, Halaman 1-11 ISSN (Online): 2337-3806.

Higgins. Robert C. 2014. Analysis for Financial Management. Seventh Edition. McGraw-Hill. Singapore.

Jiming, Li dan Weiwei, Du. 2011. An Empirical Study on the Corporate Financial Distress Prediction Based on Logistic Model Evidence from China's Manufacturing Industry. International Journal of Digital Content Technology Vol.5 No.6.

Kasmir. 2012. Analisis Laporan Keuangan. Edisi Kesebelas. Jakarta : PT. Raja Grafindo Persada.

Keown, Arthur J, dkk. 2010. Dasar-dasar Manajemen Keuangan. Jakarta: Salemba Empat. 
Khaliq., Ahmad, Basheer Hussein Motawe Altarturi, Hassanudin Mohd Thas Thaker, Md Yousuf Harun dan Nurun Nahar. 2014. Identifying Financial Distress Firms: A Case Study of Malaysia's Government Linked Companies (GLC). International Journal of Economics, Finance and Management Vol. 3, No. 3, April 2014 ISSN 2307-2466.

Kordestani, G et al. 2011. Ability of Combinations of Cash Flow Components to Predict Financial Distress. Business: Theory and Practice. Vol 12, No.3.pp 277-285.

Liana, Deny dan Sutrisno. 2014. Analisis Rasio Keuangan Untuk Memprediksi Kondisi Financial Distress Perusahaan Manufaktur. Jurnal Studi Manajemen dan Bisnis, Vol 1, No 2.

Lisiantara, G. Anggana., dan Febrina, Lilik. 2018. Likuiditas, Leverage, Operating Capacity, Profitabilitas, Sales Growth sebagai Preditor Financial Distress (Studi Empiris Pada Perusahaan Manufaktur Yang Terdaftar di Bursa Efek Indonesia tahun 2013-2016). Prosiding SENDI_U 2018 ISBN: 978-979-3649-99-3.

Listiana, Susi. 2014. Pengaruh Corporate Governance Profitabilitas, dan Leverage terhadap Financial Distress. Jurnal Ilmiah Mahasiswa Akuntansi, 1(1), 48-52.

Masdupi, Erni., Abel Tasman, dan Atri Davista. 2018. The Influence of Liquidity, Leverage and Profitability on Financial Distress of Listed Manufacturing Companies in Indonesia. 1st International Conference On Economics Education, Economics, Business and Management, Accounting and Entrepreneurship (PICEEBA 2018).

Mohammed., Ali Abusalah Elmabrok., and Ng Kim-soon. 2012. Using Altman's Model and Current Ratio toAssess the financial Status of Companies Quoted In he Malaysia Stock Exchange. International Jurnal of Scientific and Research Publications, 2 (7) Ffaculty of Technology Management, Business and Enterepreneurship, Universiti Tun Hussein Onn Malaysia.

Munawir. 2009. Analisis Laporan Keuangan. Yogyakarta: Liberty.

Needles, Belverd E. Powers, Marian. Crosson, Susan V. 2011. Financial and Managerial Accounting. Ninth Edition. South-Western: Cengage Learning.

Nisa., Umi Zhahratun, Budi Santosa, dan Stefanus Eko Wiratno. 2013. Model Prediksi Financial Distress pada Perusahaan Manufaktur go Public di Indonesia. 
Prosiding Seminar Nasional Manajemen Teknologi XVIII, Program Studi MMTITS, Surabaya 27 Juli 2013.

Pattinasarany, Christanty Amazia Immanuel. 2010. Analisis Rasio Keuangan Untuk Memprediksi Kondisi Financial Distress Pada Perusahaan Go Public. Jurnal Akuntansi. Sekolah Tinggi Ilmu Ekonomi Perbanas: Surabaya.

Pearce, J.A., and Robinson, R.B. 2009. Strategic Management. 9th ed. New York: McGraw-Hill/Irwin.

Peraturan Nomor I-I tentang Pengahapusan Pencatatan (delisting) dan Pencatatan Kembali (relisting) saham di bursa yang termuat dalam Keputusan Bursa Efek Jakarta Nomor: Kep-308/BEJ/07-2004.

Peter dan Yoseph. 2011. Analisis Kebangkrutan dengan Metode Z-Score Altman, Springate dan Zmijewski pada PT. Indofood Sukses Makmur Tbk Periode 20052009. Akurat Jurnal Ilmiah Akuntansi Nomor 04 Tahun ke-2 Januari, April.

Pratiwi, Ana., Nurkholis, dan Abdul Ghofar. Pengaruh Corporate Governance dan Struktur Kepemilikan terhadap Asimetri Informasi. JAAIVolume 19 No. 2, Desember 2015: 99-111.

Rahardjo, Budi. 2009. Analisis Fundamental Laporan Keuangan. Jakarta: Gramedia.

Rani, Dwi Rafika. Pengaruh Likuiditas, Leverage, Profitabilitas, Agency Cost dan Sales Growth terhadap Kemungkinan terjadinya Financial Distress (Studi Empiris Pada Perusahaan Manufaktur Yang Terdaftar di Bursa Efek Indonesia Tahun 2012-2015). JOM Fekon Vol. 4 No. 1 (April) 2017.

Ratna, Ikhwani \& Marwati. 2018. Analisis Faktor- Faktor Yang Mempengaruhi Kondisi Financial Distress pada Perusahaan Yang Delisting dari Jakarta Islamic Index Tahun 2012-2016. Jurnal Tabarru' : Islamic Banking and Finance Volume 1 Nomor 1, Mei 2018, p-ISSN 2621-6833, e-ISSN 2621-7465.

Santoso, Singgih. 2012. Statistik Parametik. Jakarta: PT Gramedia Pustaka Umum. Sartono, Agus. 2010. Manajemen keuangan teori, dan aplikasi. Yogyakarta: BPFE Yogyakarta.

Sawir, Agnes. 2009. Analisa Kinerja Keuangan dan Perencanaan keauangan Perusahaan. Jakarta : PT. Gramedia Pustaka Utama. 
Setiawan, Adi, R. 2012. Analisis Pengaruh Kinerja Keuangan dalam Memprediksi Pertumbuhan Laba. Jurnal Aplikasi Manajemen Vol. 10 No. 3.

Simanjutak, Christon., Farida, T., \& Aminah, W. 2017. Pengaruh Rasio Keuangan Terhadap Financial Distress (Studi Pada Perusahaan Transportasi Yang Terdaftar Di Bursa Efek Indonesia Periode 2011 - 2015). E-Proceeding of Management, 4(2), 1580-1587.

Subramanyam. K. R dan John J. Wild. 2014. Analisis Laporan Keuangan. Penerjemah Dewi Y. Jakarta: Salemba Empat.

Sudana, I Made. 2009. Manajemen Keuangan: Teori dan Praktek. Surabaya: Airlangga University.

Sugiyono. 2017. Metode Penelitian Pendidikan Kuantitatif, Kualitatif, dan R\&D. Bandung: Alfabeta.

Sujarweni, V. W. 2017. Analisis Laporan Keuangan. Pustaka Baru Press: Yogyakarta.

Surjoko, Felisca Oriana dan Vera Intanie Dewi. 2012. Konvergensi Rasio Keuangan terhadap Rata-Rata Industri Perusahaan Consumer Good yang Terdaftar pada Bursa Efek Indonesia. Parahyangan Catholic University Journal, Vol 2, 2012.

Swastha, Basu DH,. 2012. Manajemen Penjualan. Edisi 3. Yogyakarta: BPFE.

Thim, Chan Kok., Yap Voon Choong, Chai Shin Nee. 2011. Factors Affecting Financial Distress: The Case Of Malaysian Public Listed Firms. Corporate Ownership \& Control / Volume 8, Issue 4, 2011, Continued - 3.

Triwahyuningtias, Meilinda dan Harjum Muharam. 2012. Pengaruh Struktur Kepemilikan, Ukuran Dewan, Komisaris Independen, Likuiditas dan Leverage Terhadap terjadinya Kondisi Finacial Distress (Studi Pada Perusahaan Manufaktur Yang Terdaftar Di Bursa Efek Indonesia Tahun 2008-2010). Diponegoro Journal of Management Volume 1, Nomor 1, Tahun 2012, Halaman $1-14$.

Undang-Undang Republik Indonesia Nomor 4 Tahun 2009 tentang Pertambangan Mineral dan Batubara

Van Horne, James C. Wachowicz, John Martin. 2008. Fundamentals of Financial Management. Financial Times Prentice Hall. 
Widarjo, Wahyu dan Doddy Setiawan. 2009. Pengaruh Rasio Keuangan Terhadap Kondisi Financial Distress Pada Perusahaan Otomotif. Jurnal Bisnis dan Akutansi. Vol. 11 .pp. 107-119.

Widhiari, Ni Luh Made Ayu dan Ni K. Lely Aryani Merkusiwati. 2015. Pengaruh Rasio Likuiditas, Leverage, Operating Capacity, dan Sales Growth terhadap Financial Distress. E-Jurnal Akuntansi Universitas Udayana 11.2 (2015): 456-469 ISSN: 2302-8556.

Winarno, Wing Wahyu. 2013. Analisis Ekonometrika dan Statistika dengan Eviews. Yogyakarta: UUP STIM YKPN.

Wongsosudono, Corina dan Chrissa. 2013. Analisis Rasio Keuangan Untuk Memprediksi Financial Distress pada Perusahaan Sektor Keuangan Yang Terdaftar di Bursa Efek Indonesia. Jurnal Akuntansi IBBI.

Yustika, Yeni. 2015. Pengaruh Likuiditas, Leverage, Profitabilitas, Operating Capacity dan Biaya Agensi Manajerial terhadap Financial Distress. Vol 2, No 2. 